\title{
PENINGKATAN KREATIVITAS DAN KEMAMPUAN MENULIS KARANGAN NARASI MELALUI PENERAPAN MODEL EXAMPLES NON EXAMPLES DENGAN MEDIA GAMBAR SERI
}

\author{
Tri Nurhayati \\ SD Negeri 3 Linggasari, Purwokerto, Indonesia \\ email: ntrien37@yahoo.com
}

\begin{abstract}
The research was aimed to improve students' creativity and skill in writing narrative text in the Indonesia subject through Examples Non Examples with picture series aids. This classroom research consisted of two cycles. The object of the research was the fourth graders students in SDN 3 Linggasari consisted of 35 students, 19 males, and 16 females. Each cysles consisted of 4 stages, planning, implementing, observation, and reflection. The instruments used to collect the data were test and observasion sheet. To see the students' work on narrative text, they used test paper of narrative in the end of the meeting. It showed that Examples Non Examples with picture series aids could improve student's creativity and narrative writing. It could be proven from the writing outcome it first and second cycle. In the first cycle, the level of achievement was $40 \%$ an in the second cycle was $89 \%$. The students' creativity was also improving from the first to second cycle. In the first cycles, it showed $57 \%$ and $86 \%$ in the second cycle. It could be drawn that Examples Non Examples method could improve students' creativity and narrative skill for the fourth sesmester SD N 3 Linggasari.
\end{abstract}

Keywords: Narrative Writing, Creativity, Examples Non Examples Learning Model, Picture Series.

\begin{abstract}
Abstrak. Penelitian ini bertujuan untuk meningkatkan kreativitas dan keterampilan siswa dalam menulis teks naratif dalam mata pelajaran Indonesia melalui Examples Non Examples dengan alat bantu seri gambar. Penelitian kelas ini terdiri dari dua siklus. Objek penelitian adalah siswa kelas IV di SDN 3 Linggasari yang terdiri dari 35 siswa, 19 laki-laki, dan 16 perempuan. Setiap cysle terdiri dari 4 tahap, perencanaan, pelaksanaan, observasi, dan refleksi. Instrumen yang digunakan untuk mengumpulkan data adalah tes dan lembar observasi. Untuk melihat hasil karya siswa pada teks naratif, mereka menggunakan kertas tes narasi pada akhir pertemuan. Ini menunjukkan bahwa Contoh Non Contoh dengan alat bantu seri gambar dapat meningkatkan kreativitas dan penulisan naratif siswa. Itu bisa dibuktikan dari hasil penulisan itu siklus pertama dan kedua. Pada siklus pertama, tingkat pencapaian adalah $40 \%$ dan pada siklus kedua adalah $89 \%$. Kreativitas siswa juga meningkat dari siklus pertama ke siklus kedua. Pada siklus pertama, itu menunjukkan 57\% dan $86 \%$ pada siklus kedua. Dapat ditarik bahwa metode Examples Non Examples dapat meningkatkan kreativitas dan kemampuan narasi siswa untuk sesmester keempat SD N 3 Linggasari.
\end{abstract}

Kata kunci: Penulisan Naratif, Kreativitas, Contoh Model Pembelajaran Non Contoh, Seri Gambar.

PENDAHULUAN

Pelajaran Bahasa Indonesia merupakan salah satu pelajaran yang diberikan untuk memberikan keterampilan berkomunikasi siswa baik lisan maupun tulisan. Siswa bukan sekedar belajar tentang pengetahuan bahasa, melainkan belajar menggunakan bahasa untuk keperluan berkomunikasi. Tarigan (2008:1) mengatakan "pada hakikatnya, pembelajaran bahasa meliputi empat keterampilan bahasa yaitu menyimak, berbicara, membaca, dan menulis". Tujuan dari keempat keterampilan bahasa tersebut 
adalah agar siswa mampu berkomunikasi dengan menggunakan bahasa Indonesia dengan baik dan benar sesuai dengan struktur, konteks kalimat, dan kaidah bahasa, baik secara lisan maupun tulisan.

Permasalahan terkait dengan rendahnya kemampuan siswa menulis karangan juga terjadi pada siswa kelas IV SD N 3 Linggasari. Berdasarkan hasil wawancara dengan guru kelas IV SD Negeri 3 Linggasari ditemukan bahwa masih banyak siswa yang mengalami kesulitan dalam membuat karangan narasi. Dalam pelajaran menulis karangan siswa sulit mengungkapkan ide atau pemikirannya kedalam bentuk tulisan. Siswa kurang mampu menemukan dan mengembangkan ide yang akan ditulis dalam bentuk karangan, sehingga karangan yang disusun siswa kurang bahasanya kurang tepat dalam memadukan kata menjadi sebuah kalimat yang utuh dan berhubungan. Permasalahan lain yang dialami siswa kelas IV SD Negeri 3 Linggasari adalah kreativitas yang masih rendah. Kreativitas yang rendah dibuktikan dengan siswa yang kurang mengembangkan ide dalam menulis karangan. Kalimat yang dihasilkan siswa masih sedikit dalam mengarang juga menjadi bukti bahwa kreativitas siswa kelas IV SD Negeri 3 Linggasari masih rendah.

Berdasarkan kondisi tersebut di atas, peneliti dan guru sepakat melakukan kolaborasi dengan melakukan Penelitian Tindakan Kelas (PTK) untuk memperbaiki proses pembelajaran menulis karangan narasi. Upaya yang dilakukan adalah dengan menggunakan media dalam pembelajaran karangan narasi yang bertujuan untuk membantu siswa menemukan ide dan mengembangkan ide serta meningkatkan jumlah kosakata siswa sehingga diharapkan siswa dapat menulis karangan dengan lebih baik. Media yang digunakan adalah Examples non examples dengan media gambar seri.

Model Examples non Examples dengan media gambar seri dianggap tepat karena melibatkan keaktifan siswa dalam proses pembelajaran. Model Examples non Examples diharapkan dapat membantu siswa menemukan dan mengembangkan ide, gagasan untuk disusun menjadi karangan. Penggunaan gambar seri dapat lebih membantu siswa melakukan kegiatan tersebut. Penelitian tindakan kelas ini akan menggunakan model examples non examples sebagai upaya meningkatkan kreativitas dan kemampuan siswa dalam menulis karangan.

Kreativitas merupakan hasil dari interaksi antara individu dan lingkungannya. Seseorang mempengaruhi dan dipengaruhi oleh lingkungan dimana ia berada, dapat menunjang atau dapat menghambat upaya kreatif. Implikasinya ialah bahwa kemampuan kreatif dapat ditingkatkan melalui pendidikan.(Munandar, 2009:12). Semiawan (2010: 31) menyatakan bahwa kreativitas memiliki cakupan pengertian luas yang penting bagi individu maupun masyarakat. Dalam kaitan dengan individu ada rentangan yang luas dalam cakupan berbagai tugas, misalnya adalah kreativitas yang relevan dalam mengatasi masalah berkenaan dengan tugas manusia.

Dalam kamus besar bahasa Indonesia edisi ketiga (2007: 707), kemampuan berasal dari kata "mampu" yang berarti kuasa (bisa, sanggup, melakukan sesuatu, dapat, berada, kaya, mempunyai harta berlebihan).

Menurut Nurjamal dan Sumirat, (2010: 68) menulis merupakan sebuah proses kreatif menuangkan gagasan dalam bentuk bahasa tulis untuk tujuan, misalnya 
memberi tahu, meyakinkan, menghibur. Hasil dari proses kreatif ini bisa disebut dengan istilah tulisan atau karangan. Istilah menulis sering dilekatkan pada proses kreatif yang berjenis ilmiah. Sementara, istilah mengarang sering dilekatkan pada proses kreatif yang berjenis non ilmiah. Langan (2001:13) "writing is a process of discovery involving a series of steps, and those steps are very often a zigzag journey". langan menggambarkan bahwa menulis merupakan proses penemuan yang melibatkan serangkaian langkah, dan langkah-langkah yang sangat sering perjalanan zigzag. Menurut Hartati (2006: 28) komunikasi tertulis adalah membaca dan menulis. Kedua ragam komunikasi menulis ini tidak dapat dipisahkan satu sama lain. Komunikasi tertulis telah dikenal sebelum anak-anak masuk sekolah dengan bimbingan orang tua di lingkungan keluarganya anak mencoba untuk melatih dirinya dengan mencoret-coret hal yang baru dilihat dan dibacanya.

Menurut Keraf (2007: 135)

mengungkapkan karangan narasi merupakan suatu bentuk wacana yang berusaha menggambarkan sejelas-jelasnya suatu objek sehingga objek itu seolah-olah berada di depan mata kepala pembaca, maka narasi merupakan suatu bentuk wacana yang berusaha mengisahkan suatu kejadian atau peristiwa sehingga tampak seolah-olah pembaca melihat atau mengalami sendiri peristiwa itu. Sebab itu unsure yang paling penting pada sebuah narasi adalah unsure perbuatan atau tindakan. Menurut Resmini (2008: 135) karangan narasi adalah karangan yang menyajikan serangkaian peristiwa.

Menurut Santoso (2011: 1) model pembelajaran examples non examples adalah model pembelajaran yang menggunakan media gambar dalam penyampaian materi pembelajaran yang bertujuan mendorong siswa untuk belajar berfikir kritis dengan jalan memecahkan permasalahan-permasalahan yang terkandung dalam contoh-contoh gambar yang disajikan.

Menurut Arsyad (2009:119) gambar seri adalah gambar yang merupakan rangkaian kegiatan atau cerita disajikan secara berurutan.

\section{METODE PENELITIAN}

Penelitian dilakukan di kelas IV SD Negeri 3 Linggasari yang terletak di Desa Linggasari Kecamatan Kembaran Kabupaten Banyumas. Penelitian dilakukan semester II tahun ajaran 2013/2014. Subjek yang akan diteliti adalah siswa kelas IV SD Negeri 3 Linggasari, Kembaran, Banyumas. Jumlah siswa 35 anak, terdiri dari siswa laki-laki 19 dan siswa perempuan 16. Penelitian dilakukan pada kelas IV dikarenakan kreativitas dan kemampuan menulis karangan narasi siswa kelas IV SD Negeri 3 Linggasari tergolong masih rendah.

Jenis penelitian adalah penelitian tindakan kelas (PTK) yang terdiri 2 siklus, masing-masing siklus terdiri dari 2 pertemuan. Pada masing-masing siklus terdiri dari tahapan-tahapan yaitu perencanaan, pelaksanaan tindakan, pengamatan, dan refleksi. Data yang diperoleh dalam penelitian ini yaitu: tes kemampuan dan kreativitas menulis karangan narasi siswa yang diambil dari evaluasi yang dilakukan pada setiap akhir pertemuan. Data tentang aktivitas siswa diperoleh dari hasil observasi kegiatan siswa yang dilakukan oleh observer II. Data 
tentang aktivitas guru dalam melakukan kegiatan pembelajaran diambil dari hasil observasi kegiatan guru.

HASIL DAN PEMBAHASAN
1. Kemampuan menulis karangan narasi

Hasil kemampuan menulis karangan narasi yang diperoleh dari hasil evaluasi yang dilaksanakan setiap akhir pertemuan dengan rekapitulasi yang disajikan pada Tabel 1 .

\section{Tabel 1}

Rekapitulasi Nilai Kemampuan Menulis Narasi Siklus I dan Siklus II

\begin{tabular}{|l|c|c|}
\hline \multirow{2}{*}{\multicolumn{1}{|c|}{ Pencapaian }} & \multicolumn{2}{c|}{ Siklus } \\
\cline { 2 - 3 } & I & II \\
\hline Nilai Terendah & 47 & 60 \\
\hline Nilai Tertinggi & 84 & 87,5 \\
\hline Rata-rata Kelas & 65,02 & 73,91 \\
\hline Nilai KKM & 70 & 70 \\
\hline Yang Tuntas KKM & 20 & 30 \\
\hline Yang belum Tuntas KKM & 15 & 5 \\
\hline
\end{tabular}

Hasil peningkatan kemampuan menulis karangan narasi siswa disajikan dalam gambar 1. Berdasarkan gambar 1 diketahui data PTK dari siklus I sampai siklus II mengalami peningkatan dari nilai terendah dan nilai tertinggi. Pada siklus I nilai terendah pada nilai 47 , nilai tertinggi berada pada nilai 84 dan rata-rata 65,02 sedangkan pada siklus II nilai terendah telah mencapai nilai 60 , nilai tertinggi telah mencapai nilai 87,5 dan rata-rata 73,91 . Peningkatan pada siklus I dan siklus II terjadi karena guru telah menerapkan model examples non examples dengan media gambar seri pada pembelajaran menulis karangan narasi sehingga siswa merasa mudah untuk memunculkan dan mengembangkan ide untuk menulis karangan narasi.

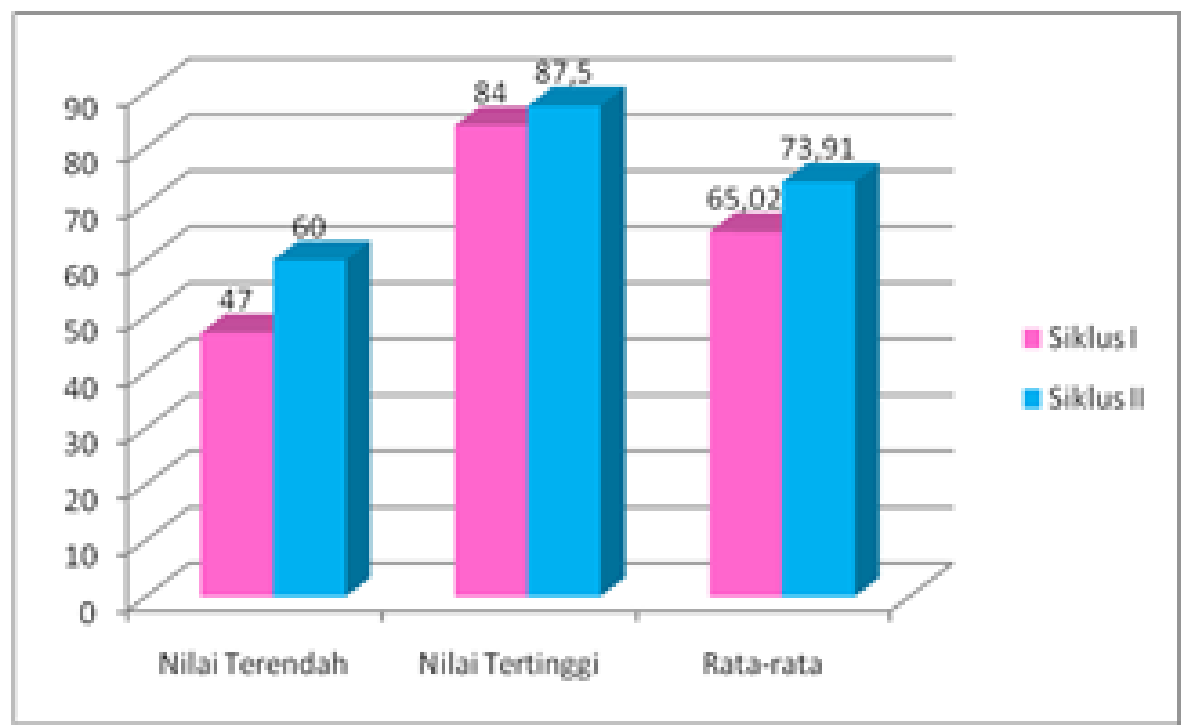

Gambar 1 Histogram Peningkatan Kemampuan Menulis Karangan Narasi

2. Kreativitas menulis karangan narasi
Hasil kreativitas menulis karangan narasi yang diperoleh dari hasil evaluasi yang 
dilaksanakan setiap akhir pertemuan dengan penilaian yang disajikan pada tabel 2 .

Tabel 2

Hasil Penilaian Kreativitas Menulis Karangan Narasi Siklus I dan Siklus II

\begin{tabular}{|l|c|c|}
\hline \multicolumn{2}{|c|}{ Pencapaian } & \multicolumn{2}{c|}{ Siklus } \\
\cline { 2 - 3 } & Siklus I & Siklus II \\
\hline Nilai Terendah & 50 & 52,5 \\
\hline Nilai Tertinggi & 75 & 87,5 \\
\hline $\begin{array}{l}\text { Yang mendapat nilai dengan kriteria } \\
\text { baik }\end{array}$ & 20 & 30 \\
\hline $\begin{array}{l}\text { Yang belum mendapat nilai dengan } \\
\text { kriteria baik }\end{array}$ & 15 & 5 \\
\hline $\begin{array}{l}\text { Presentase hasil nilai kreativitas } \\
\text { dengan kriteria baik }\end{array}$ & $57 \%$ & $86 \%$ \\
\hline
\end{tabular}

Tabel 2 menunjukkan bahwa terjadi peningkatan jumlah siswa yang memperoleh nilai kreativitas dengan kriteria baik. pada siklus I jumlah siswa yang memperoleh nilai kreativitas dengan kriteria baik adalah $57 \%$. Sedangkan pada siklus II telah mencapai 86\%. Peningkatan pada siklus I dan II terjadi karena siswa telah mampu mengembangkan pokok pikiran utama sehingga karangan narasi siswa jumlah kata-katanya menjadi banyak. Siswa juga telah menggunakan berbagai macam kalimat dengan baik sehingga karangan narasi siswa terlihat lebih kreatif dari siklus I ke siklus II.

Gambaran umum secara keseluruhan kemampuan dan kreativitas menulis karangan narasi siswa dapat dikatakan meningkat. Ketuntasan belajar siswa pada siklus I diperoleh ketuntasan belajar klasikal sebesar $40 \%$. Pada siklus II diperoleh ketuntasan belajar klasikal sebesar $89 \%$. Pada lembar observasi sktivitas siswa mengalami peningkatan. Hal ini terlihat dari nilai mutu 56,02 meningkat menjadi 71,74 pada siklus II. Dengan kata lain aktivitas siswa meningkat dari kriteria cukup pada siklus I menjadi kriteria baik pada siklus II.

\section{SIMPULAN DAN SARAN}

Dari hasil penelitian diperoleh bahwa kreativitas dan kemampuan menulis karangan narasi siswa kelas IV SD Negeri 3 Linggasari dapat mengalami peningkatan melalui penerapan model examples non examples dengan media gambar seri. Peningkatan tersebut dapat dibuktikan dalam keberhasilan dari ketuntasan belajar klasikal pada siklus I memperoleh $40 \%$ meningkat menjadi $89 \%$ pada siklus II. Kreativitas siswa juga meningkat dari 57\% menjadi $86 \%$ pada siklus II.

Saran dalam penelitian ini yaitu guru harus bisa menjelaskan langkahlangkah pembelajaran kepada siswayang baik sehingga akan menimbulkan kejelasan pada siswa dan hasil akhir pembelajaran akan sesuai dengan harapan. Guru harus memantau siswa saat pelaksanaan pembelajaran menulis karangan narasi karena tidak semua siswa akan berkonsentrasi dalam menulis sehingga dapat mengurangi siswa yang sibuk bermain sendiri atau ramai sendiri saat pembelajaran menulis. Media pembelajaran menggunakan gambar seri digunakan dalam proses pembelajaran Bahasa Indonesia khusunya pada materi menulis. Hal ini 
dikarenakan media gambar dapat mengembangkan imajinasi dalam menulis karangan dan mengembangkan kemampuan siswa dalam menulis karangan seperti pemilihan kata menjadi kalimat sesuai runtut cerita gambar.

\section{DAFTAR PUSTAKA}

Arsyad, A. 2009. Media Pembelajaran. Jakarta: PT Rajagrafindo Persada.

Depdiknas. 2007. Kamus Besar Bahasa Indonesia Edisi Ketiga. Jakarta: Balai Pustaka.

Hartati T, Ernalis, Churiyah Y. 2006. Pendidikan dan Sastra di Kelas Rendah. Bandung: UPI PRESS.

Keraf, Gays. 2007. Argumentasi dan Narasi. Jakarta: PT. Gramedia Pustaka Utama.

Langan, J. 2001. College Writing Skills with Readings. Singapore: McGraw-Hill.

Munandar, U. 2009. Pengembangan Kreativitas Anak Sekolah. Jakarta: PT. Rineka Cipta.

Nurjamal, D \& Sumirat, W. 2010. Penuntun Perkuliahan Bahasa Indonesia. Bandung: Alfabeta.

Resmini N, Churiyah Y, Sundori N. 2008. Membaca Menulis di SD. Bandung: UPIPRESS.
Santoso, Eko Budi. 2011. Model Pembelajaran Examples non Examples. (Online). Tersedia: http://ras-eko.blogspot.com/ 2011/05/model-pembelajaranexamples-non-examples.html. (15 Desember 2013)

Semiawan, Conny. 2010. Kreativitas Keberbakatan. Jakarta Barat: PT. Indeks.

Tarigan, Henry Guntur. 2008. Membaca Sebagai Suatu Ketrampilan Berbahasa. Bandung: Penerbit Angkasa Bandung 